\title{
Koszorúérsztent-bevonatok fejlesztési lehetőségei
}

\section{Development options for coronary stent coatings}

\author{
Izsó Izabella, ${ }^{1}$ Asztalos Lilla ${ }^{2}$ \\ Budapesti Müszaki és Gazdaságtudományi Egyetem, Gépészmérnöki Kar, Anyagtudomány és Technológia \\ Tanszék, Budapest, Magyarország \\ 1 izso.izabella@gmail.com \\ 2 lilla@eik.bme.hu
}

\begin{abstract}
In our research we investigated the effect of different surface qualities on the adhesion of polylactic acid coating on 316L steel. During the study, samples were electropolished and surface treated with aqua regia and Vilella reagent, and the coating was applied by dipping technology using a Yaskawa robot arm. Tribology tests were carried out to determine the adhesion, in addition to the force and friction conditions, the coating damage resulting from the measurements was also recorded. In addition to the coating adhesion assay, contact angle measurements were also performed. Based on our measurement results, it was found that compared to the three different surface treatment methods, the surface of the samples treated with Villella was more adherent to the polymer than to the conventional electropolished surface. In this case, the frictional force was also much lower than that of the polished specimens, therefore this surface treatment method may be suitable for improving the adhesion of the coating.
\end{abstract}

Keywords: coronary stent, surface treatment, coating adhesion, PLA.

\section{Összefoglalás}

Kutatómunkánkban a különböző felületminőségek hatását vizsgáltuk a politejsav bevonat tapadására 316L acéllapkákon. A vizsgálat során elektropolírozott, valamint királyvízben és Vilella-reagensben felületkezelt mintákat készítettünk elő, amelyekre a bevonatot robotkar segítségével, mártogatásos eljárással vittük fel. A tapadás minősítésére tribológiai vizsgálatokat végeztünk el, az erő- és súrlódási viszonyokon túl a mérések során keletkezett bevonatkárosodást is rögzítettük. A bevonattapadási vizsgálaton túl peremszögmérést is végeztünk. Mérési eredményeink alapján megállapítottuk, hogy a három különböző felületkezelési módszert összehasonlítva a Villelával kezelt lapkák felületéhez a polimer jobban tapadt, mint a hagyományosan elektropolírozott felülethez. Ez esetben a súrlódási erő is sokkal kisebb volt, mint a polírozott minták esetében, így ez a felületkezelési módszer alkalmas lehet a bevonat tapadásának javítása céljából.

Kulcsszavak: koszorúérsztent, felületkezelés, bevonattapadás, politejsav.

\section{Bevezetés}

A bevonatokat eleinte a sztentek biokompatibilitásának fokozására alkalmazták, viszont napjainkban elsődleges céljuk a neointimálos hiperplázia gátlására használt gyógyszerek szabályozott bejuttatása. Az optimális sztentbevonatot illetően a szakirodalom három fő szempontot emel ki. Az első és egyben egyik legfontosabb tényező, hogy a bevonatolást szennyeződésmentes fémfelületen kell elvégezni. Másodszor, a felületi érdességnek minimálisnak kell lennie a bevonat vastagságához képest, hogy a filmréteg jó egységességét és tapadását biztosítsa. Továbbá, végül, a bevonatnak stabilnak kell lennie mind a sztentre való felhelyezésekor, mind pedig beültetés után [1, 2]. A resztenózis kezelésében mélyrehatóan vizsgált három gyógyszer a heparin, a szirolimusz és a paklitaxel. A heparin hatásos volt mind a trombózis, mind a neointimális proliferáció csökken- 
tésében, míg a szirolimuszt és a paklitaxelt főként antiproliferatív hatásaikban alkalmazták a neointimális hiperplázia blokkolására [3, 4].

A megfelelő felületkezelés fontos szerepet játszik egy sztent tervezésekor, illetve gyártásakor. A felület érdesítése növelheti a bevonat tapadását, de a túl durva felület hajlamosít a trombogenitásra. A klinikai gyakorlatban alkalmazott sztenttípusok jellemző felületkezelési módszere az elektropolírozás [5, 6].

Korábbi kutatásainkban megfigyeltük, hogy a sztent felületéről a bevonat már az implantálás során leválhat, aminek a hátterében az áll, hogy a gyógyszeres hatóanyagot hordozó műanyag bevonat nem tapadt rá megfelelően a hordozó fémváz felületére [7]. Jelen kutatásunk célja, hogy a korábbi tapasztalatok [8] figyelembevételével olyan felületkezelési módszert dolgozzunk ki, amellyel javítható a 316L típusú, ausztenites korrózióálló acélon a politejsav bevonat tapadása.

\section{Módszerek}

A kutatáshoz $30 \times 30 \times 0,3$ mm, méretű, 316L típusú, ausztenites korrózióálló acélból készült lapkákat használtunk. Öt próbatestet elektropolíroztunk, öt próbatestet királyvízben (20 mL metanol, $15 \mathrm{~mL} \mathrm{65 \% -os} \mathrm{HNO}_{3}, 45 \mathrm{~mL} 37 \%$-os $\mathrm{HCl}, 60$ s-ig, áramforrás nélkül), ötöt pedig Vilella-reagensben (200 mL etanol, 2 g pikrinsav, $10 \mathrm{~mL} \mathrm{37 \% -os} \mathrm{HCl}$, $60 \mathrm{~s}$-ig, $5 \mathrm{~V}$-on) kezeltünk. A felületkezeléseket $30 \pm 1{ }^{\circ} \mathrm{C}$-on végeztük. Továbbá a mintákat a felületmódosítás előtt és után a robotba előre beprogramozott értékek alapján acetonnal és etanollal megtisztítottuk, majd hagytuk megszáradni (háromszori acetonos, ill. etanolos tisztítás).

\subsection{Elektropolírozás}

A különböző felületkezelési módszerek közül az elektropolírozás az egyik legnépszerübb felületmódosító eljárás, ami számos előnyének köszönhető. Ezek közül az egyik az, hogy komplex formákon is elvégezhető, mint például eltérő formájú és geometriájú koszorúérsztenteken. Segítségével egy jól passzivált, sima, hibamentes és szennyeződésmentes felület képezhető. A polírozási folyamat során a fém oxidálódik az anód felületén, amelynek hatására az ionok kioldódnak az elektrolitoldatba, majd a katód felé vándorolnak, ahol hidrogén keletkezése mellett redukálódnak. Az elektropolírozási folyamatot számos paraméter befolyásolja. Ilyen paraméterek közé tartozik az anódos áramsürüség, az alkalmazott potenciál, az elektrolit hőmérséklete, a polírozási idő, az elektrolitok összetétele és koncentrá- ciója, a keverési módszer és az anód-katód felületi arány [9-12]. E kutatások és tapasztalataink alapján az elektropolírozást 5 V-os feszültségen és $0,01 \mathrm{~A} / \mathrm{mm}^{2}$ áramerősségen, szobahőmérsékletű oldatban $\left(25 \pm 1^{\circ} \mathrm{C}\right)$, ultrahangos rezegtetéssel, foszforsav $\left(\mathrm{H}_{3} \mathrm{PO}_{4}\right)$, kénsav $\left(\mathrm{H}_{2} \mathrm{SO}_{4}\right)$ és desztillált víz 6:3:1 arányú elegyében végeztük, amelyhez 20 mL glicerint kevertünk. A polírozási idő $180 \mathrm{~s}$ volt (1. ábra).

\subsection{Kémiai maratás}

Az elektropolírozással egy nagyon sima felületet hozhatunk létre, viszont a bevonat tapadását elősegíthetjük azzal, hogy a felületet kémiai maratással érdesítjük. Poliuretán bevonatok fejlesztése során már végeztek hasonló kísérleteket, amelyek révén már bizonyították, hogy minél kisebb a sztentfelület érdessége, annál könnyebben le tud válni róla a bevonat [13]. A poliuretán viszont már nem jellemző gyógyszerhordozó anyag az orvostechnikában, így a kutatási és fejlesztési trendeket figyelembe véve jelen kutatásban politejsav tapadását vizsgáljuk.

A felület érdesítését kémiai maratással oldottuk meg. Annak érdekében, hogy a folyamat megismételhető legyen, a folyamatot robotkarral (Yaskawa You tech me) automatizáltuk. A marószert mágneses keverővel (IKA RCT basic) folyamatosan kevertettük $30 \pm 1^{\circ} \mathrm{C}$-on. A felületkezelés időtartama 60 másodperc volt, amely alatt a robotkar körkörösen mozgatta a próbatestet az oldatban (2. ábra).

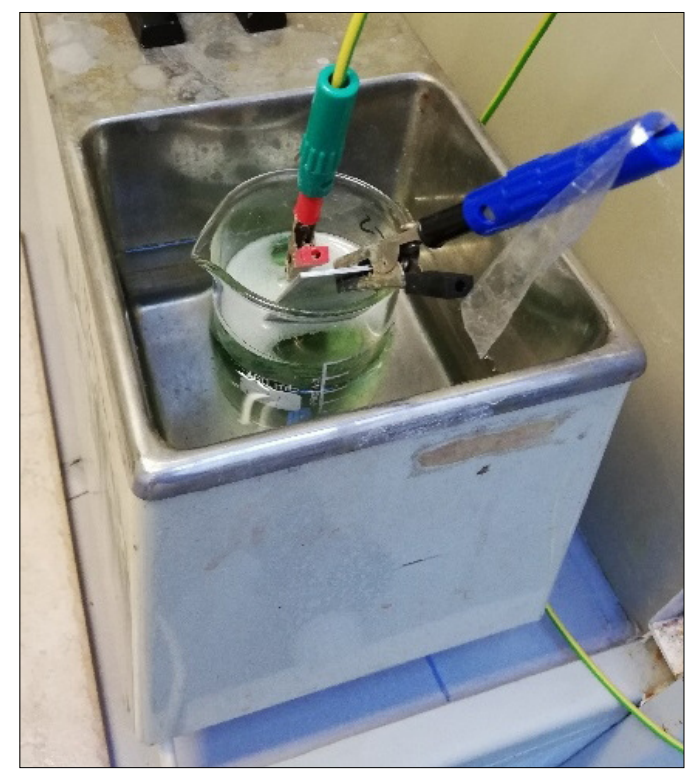

1. ábra. Az elektropolírozás folyamata 


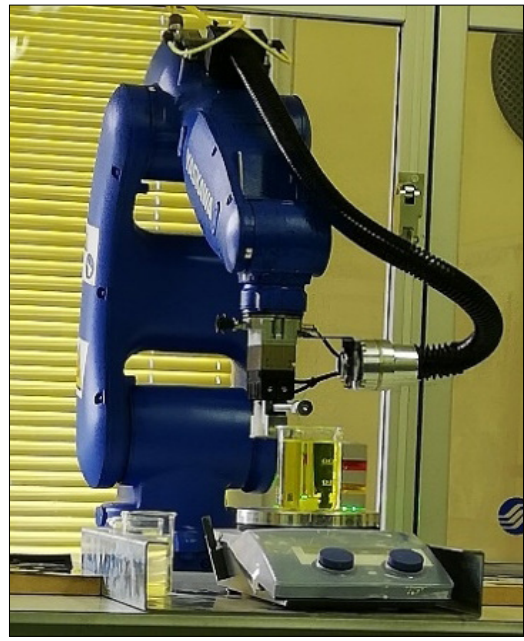

2. ábra. Felületkezelés a Yaskawa „You teach me” robotkar segítségével

\subsection{Bevonatkészítés}

A bevonatot a felületkezelt lapkákra szintén automatizálva, a robotkarral vittük fel. A politejsavat kloroformban oldottuk. A bemártási idő 10 másodperc volt, a kihúzás után pedig a tengelye mentén forgatva szárítottuk a lapkán képződött bevonatot.

\subsection{A bevonat minősítése}

A lapkák tömegét a felületkezelések előtt, után, valamint a bevonatkészítést követően is mértük. A felületkezelés eredményességét elektronmikroszkóppal (Zeiss EVO MA 10) és konfokális mikroszkóppal (Sensofar, neox PLu) vizsgáltuk. A felületi érdességet referencia-, felületkezelt és bevont mintákon is mértük. A bevonat tapadását tribológiai vizsgálattal (High Temperature Tribometer - CSM Switzerland) értékeltük. Mivel az orvostechnikában fontos az, hogy az adott mủanyag milyen nedvességmegkötő hatással bír, peremszögmérést is végeztünk a kutatás részeként.

\section{Eredmények}

\subsection{Mikroszerkezeti vizsgálatok}

$\mathrm{Az}$ alkalmazott felületkezelési eljárások különböző felületi morfológiát hoztak létre, amelyek pásztázó elektronmikroszkópos képe (SEM) a 3-5. ábrákon láthatók. Az elektropolírozással, ahogyan az várható volt, sima felületet kaptunk, míg a Vilellával és királyvízzel mart minták esetében a felület érdesedését értük el. A kezelések után kapott felületek mindegyike alkalmas lehet az általunk választott polimer bevonat felvitelére.

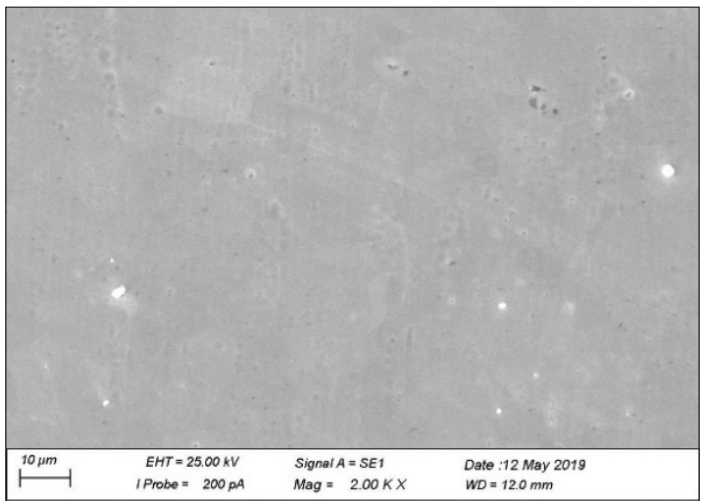

3. ábra. 316L lapka felületéről készített elektronmikroszkópos felvétel elektropolírozás után

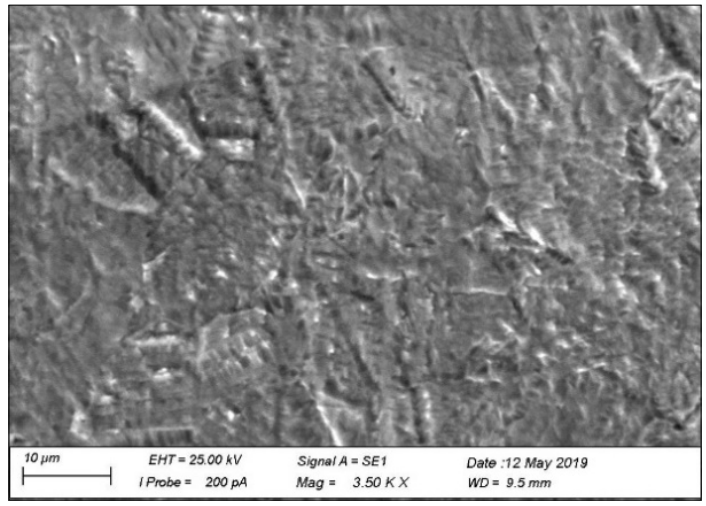

4. ábra. 316L lapka felületéről készített elektronmikroszkópos felvétel királyvizes maratás után

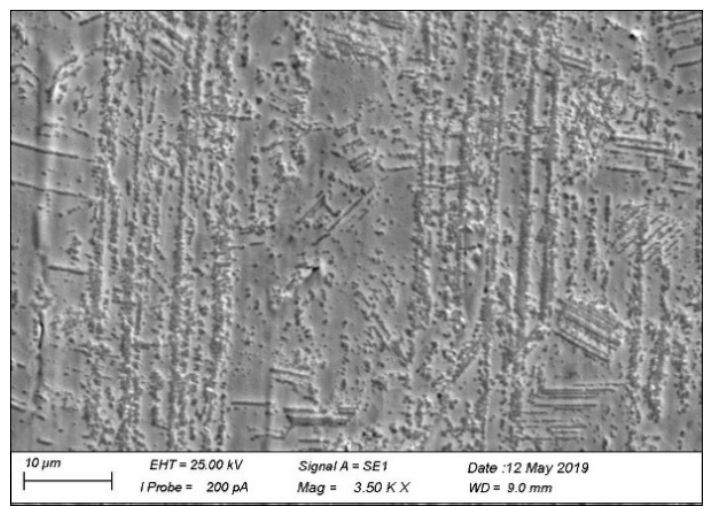

5. ábra. 316L lapka felületéről készített elektronmikroszkópos felvétel vilellás maratás után

\subsection{Tömegmérés}

A legnagyobb tömegveszteséget az elektropolírozási eljárás okozta (6-8\%), ezt követi a királyvizes (0,5-1\%), majd a Vilella marószer okozta tömegcsökkenés $(0,2-0,3 \%)$. 
1. táblázat. A mintákon mért felületi érdesség ( $S a=a z$ eltérések átlaga). Az egyes értékek az 5 próbatesten mért eredmények átlaga

\begin{tabular}{|l|c|}
\hline \multicolumn{1}{|c|}{ Minta } & Sa $(\boldsymbol{\mu m})$ \\
\hline Királyvízben mart & 5,12 \\
\hline Vilellával mart & 4,53 \\
\hline Elektropolírozott & 2,66 \\
\hline Referencia & 2,73 \\
\hline
\end{tabular}

2. táblázat. SA mintákon mért felületi érdesség a bevonatkészités után ( $\mathrm{Sa}=$ az eltérések átlaga). Az egyes értékek a 4 próbatesten mért eredmények átlaga

\begin{tabular}{|l|c|}
\hline \multicolumn{1}{|c|}{ Minta } & Sa $(\boldsymbol{\mu m})$ \\
\hline Királyvízben mart & 1,33 \\
\hline Vilellával mart & 1,37 \\
\hline Elektropolírozott & 1,53 \\
\hline Referencia & 1,30 \\
\hline
\end{tabular}

A bevonatkészítés után a lapkák tömege egységesen 6-7 mg-mal növekedett, ami alátámasztja a bevonatolás automatizálásának sikerességét.

\subsection{Felületi érdesség}

A felületi érdességet konfokális mikroszkóppal (Neox Flu, Sensofar) határoztuk meg. A királyvízben maratott minták felületi érdessége a legnagyobb, a kezelt minták közül csupán az elektropolírozott próbatesten mértünk a referenciaértéknél kisebb érdességet (1. táblázat).

A bevonat elkészítése utáni értékeket a 2. táblázatban foglaltuk össze. A bevonatolás után minden minta esetében csökkent az átlagos felületi érdesség, ami előnyös, mivel a beültetés során a kis felületi érdesség csökkenti az implantátum éren belüli mozgatásához szükséges erőt.

\subsection{Bevonatvastagság}

A bevonat vastagságának meghatározása szintén konfokális mikroszkóppal történt. Ennek érdekében minden típusból kiválasztottunk lapkákat, amelyeken a bevonatolt szakasz feléről mechanikus módon eltávolítottuk a bevonat egy részét úgy, hogy se az alapanyag, se a maradó bevonatszakasz ne sérüljön, mivel a nem teljes hosszon történő bemártás miatt az eredeti határvonalon nem lehetne megfelelően rétegvastagságot mérni, mert az fokozatos elvékonyodást mutatna. Az így létrejött határszakasz (6. ábrán sárgával jelölve), teljes hosszát vizsgálva, a minta

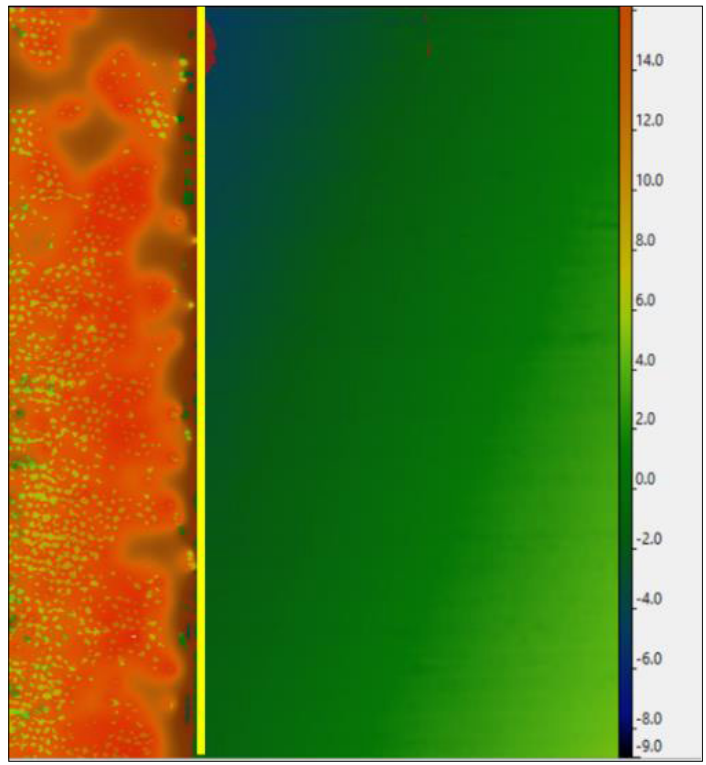

6. ábra. A rétegvastagság megállapításához tartozó színskála. Az elmetszés során létrejött határszakaszt sárga színnel jelöltük. A jobb oldali skála $\mu \mathrm{m}$ mértékegységben mutatja az egyes színekhez tartozó szintek mélységét, illetve magasságát

felületének átlagos szintje (zöldes terület a 6. ábrán) és a bevonat átlagos vastagságának szintje (narancssárga terület a 6. ábrán). közti különbség kiszámításával kapjuk a bevonatvastagságot. A jelenleg általunk alkalmazott robotkaros módszer sajnos nem tette lehetővé, hogy a mintákat teljes hosszukban a polimerbe mártsuk, mivel a befogó együtt merült volna el a mintadarabbal a műanyagoldatba. A befogón és a lapkán együtt szilárdulna meg a politejsav bevonat, és a befogó eltávolítása során akár a lapka bevonata is sérült volna. A jövőben célunk a jelenlegi módszer oly módú továbbfejlesztése, hogy a mintákat teljes hosszukban képesek legyünk bemártani a politejsavba, hogy a rétegvastagság minél egyenletesebb legyen a minta teljes hosszán.

Az alkalmazott konfokális mikroszkóp szoftvere lehetővé tette a színtérképes ábrázoláson túl kijelölt pontokban, valamint egyenesek mentén is a pontos magassági, illetve mélységi értékek meghatározását. A 7. ábrán három, vonal menti elemzés értékei láthatók. A mérési vonalakat a határvonalra merőleges irányban vettük fel. Meghatároztuk a bevonatréteg átlagos magasságát (felső vízszintes kék vonal), valamint a lemez síkjának átlagos magasságát (alsó vízszintes kék vonal), és a kettő különbségéből megkapjuk a bevonat 


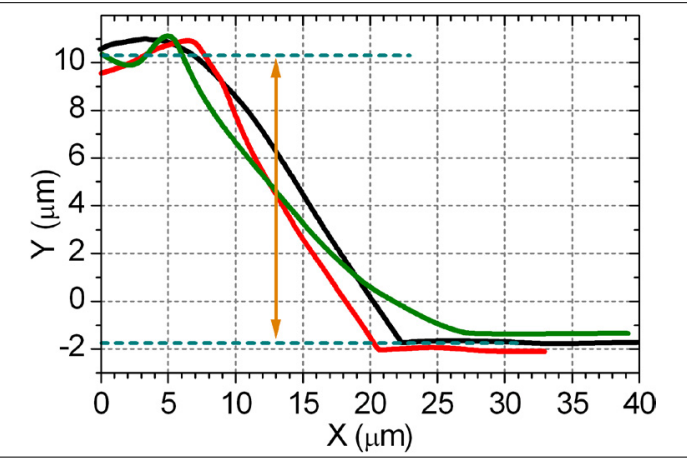

7. ábra. A konfokális mikroszkópos mérés lapkák rétegvastagságának eredményei. A felső kék vonal jelöli a bevonatréteg átlagos magasságát, az alsó kék vonal pedig a lemez síkjának átlagos magasságát. A sárga nyíl a bevonatvastagságot mutatja

vastagságát (függőleges sárga nyíl). A három különböző görbén láthatjuk, hogy a bevonat szélén hirtelen csökkenésnek indul a minta magassága, majd ezután egy szintén jól elkülöníthető pontban átáll a lemez átlagos szintjére.

Az eredmények alapján az általunk készített bevonat átlagos vastagsága 10,45 $\mu \mathrm{m}$, ami eleget tesz a szakirodalmi értékeknek, valamint szinte azonos a jelenleg forgalomban lévő sztentek jellemző bevonatvastagságával.

\subsection{A bevonattapadás minősítése}

A bevonat tapadásának minőségét tribológiai vizsgálattal állapítottuk meg, amely méréshez a High Temperature Tribometer CSM THT müszert használtuk Kassán a PROMATECH laborjaiban. A vizsgálat során azonos terhelőerőt alkalmazva, ami esetünkben $50 \mathrm{~N}$, egy tárcsán lévő tüt mozgatunk körkörösen a lapka felületén. A tű által kialakított „árok” egy részletét mutatja a 8. ábra.

A kísérlet alapján azt tapasztaltuk, hogy azonos terhelőerő hatására a legkisebb mélységű árok $(8,76 \mu \mathrm{m})$ a Vilellával kezelt minták esetében keletkezett. Ez alapján azt mondhatjuk, hogy a felvitt polimer bevonat itt volt a legellenállóbb azonos terhelés hatására. Ezen esetben a tű el sem érte a minta fémes anyagának határfelületét, ha a 10,45 $\mu$ m-es átlagos bevonatvastagságot veszszük alapul. Ezzel szemben a királyvízzel kezelt $(17,5 \mu \mathrm{m})$ és az elektropolírozott $(16,9 \mu \mathrm{m})$ minták esetében mélyebb, a bevonat vastagságát túlhaladó különbség adódott. A legmélyebb karcmélységet $(35,2 \mu \mathrm{m})$ a kezeletlen, de polimerrel bevont minták esetében kaptuk, vagyis ez volt a legkevésbé „ellenálló” azonos terhelés hatására.

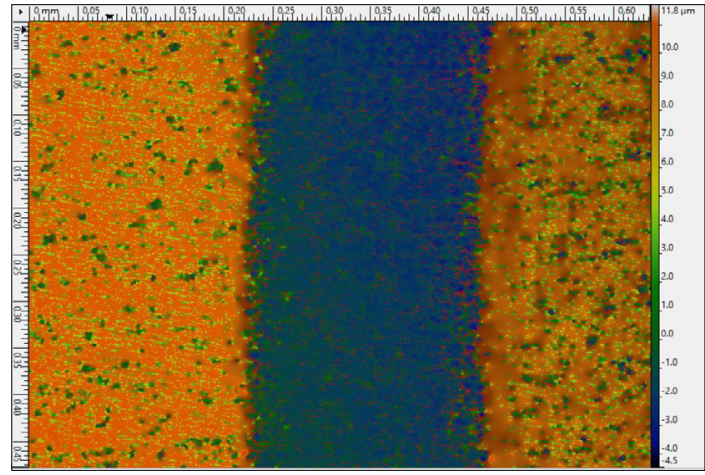

8. ábra. A tribológiai vizsgálat során a tü által kialakított „árok” egy részlete

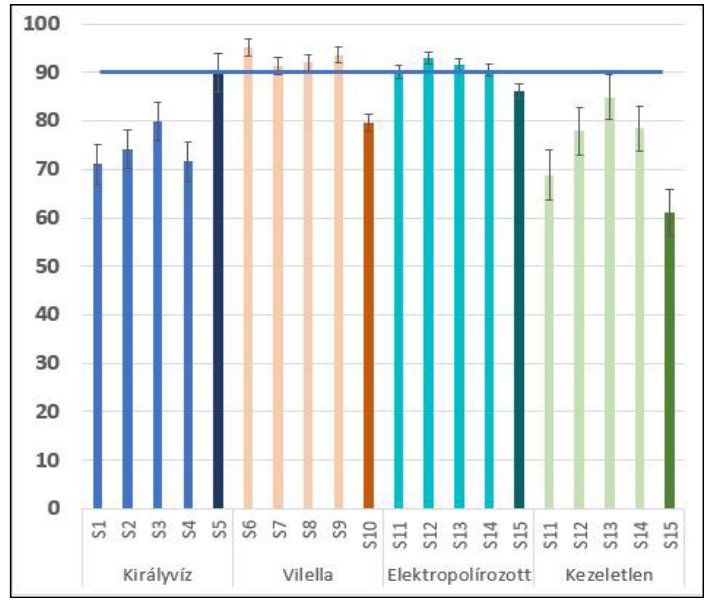

9. ábra. A peremszögmérés eredményei. $A z S 5, S 10$, S15 és S20 minták a bevonat nélküli referenciadarabok

\subsection{Peremszögmérés}

A peremszögmérésnél a lapkák nedvesíthetőségét vizsgáljuk. Az adatokból következtethetünk arra, hogy a vér nedvesíti-e a felületet vagy sem. Ez lényeges, mert a felület hidrofób vagy hidrofil mivolta befolyásolhatja a bevonat resztenózisra gyakorolt hatását. A kisebb peremszögértékek jobb nedvesítést jelentenek (minimum $0^{\circ}$ ), míg a nagyobb peremszög (maximum $180^{\circ}$ lehet) roszszabb nedvesítést jelent. A $90^{\circ}$-nál kisebb peremszög esetén mondjuk, hogy a folyadék nedvesíti a hordozó szilárd felületét, és $90^{\circ}$-nál nagyobb peremszögeknél beszélünk nemnedvesítésről. A mérési eredményeinket a 9. ábra foglalja össze.

A 9. ábra alapján láthatjuk, hogy a Vilellával kezelt minták felületére felvitt polimernek $90^{\circ}$ feletti a nedvesíthetősége, vagyis a bevonat inkább hidrofób jelleget mutat, akárcsak az elektropolírozott minták esetében. Ebből arra következ- 
tethetünk, hogy a vér kevésbé nedvesíti polimerünk felületét. Ez azért jó, mert így a trombociták, vagyis a vérlemezkék kevésbé fognak kitapadni az „idegen” anyag falára, és kevesebb valószínüséggel okoz ezáltal trombózist.

\section{Következtetések}

A fenti eredményeket összegezve kutatásunk során arra jutottunk, hogy az irodalomban is alkalmazott marató oldatok jól felhasználhatók a 316L anyagtípus esetében és szép, egyenetlen felületet hoznak létre, amelyek hatással vannak a bevonattapadás tulajdonságaira. Továbbá megállapítottuk, hogy a három különböző felületkezelési módszert összehasonlítva a Vilellával kezelt lapkák felületéhez a polimer jobban tapadt, mint a jelenleg legelterjedtebben alkalmazott módszer által kialakított elektropolírozott felülethez. Ez esetben a súrlódási tényezők is sokkal kisebbek voltak, mint a polírozott minták esetében, így ez a felületkezelési módszer alkalmas lehet a bevonat tapadásának erősítése céljából. Továbbá ezen felületkezelési eljárás alkalmazásával a peremszögértékek, vagyis a nedvesíthetőségi feltételek alapján is azt mondhatjuk, hogy jobb eredményre jutottunk, mint a hagyományos elektropolírozási eljárás során.

Mindazonáltal sikerült automatizálni a felületkezelési és bevonatolási folyamatokat, illetve megfelelő felületkezelési módszert találni a jobb bevonattapadást illetően 316L lapkákon, azonban további kutatásokra és vizsgálatokra van szükség sztenteken is.

\section{Köszönetnyilvánítás}

Az Emberi Erőforrások Minisztériuma ÚNKP-18-3-II kódszámú Új Nemzeti Kiválóság Programjának támogatásával készült.

\section{Szakirodalmi hivatkozások}

[1] Nazneen F., Herzog G., Arrigan D. W. M., Caplice N., Benvenuto P., Galvin P., Thompson M.: Surface chemical and physical modification in stent technology for the treatment of coronary artery disease. Journal of Biomedical Materials Research - Part B Applied Biomaterials 100B/7. (2012) 1989-2014. https://doi.org/10.1002/jbm.b.32772

[2] Sydow-Plum G., Tabrizian M.: Review of stent coating strategies: clinical insights. Materials Science and Technology, 24/9. (2008) 1127-1143. https://doi.org/10.1179/174328408X341816

[3] Mani G., Feldman M. D., Patel D., Agrawal C. M.: Coronary stents: A materials perspective. Biomaterials, 28/9. (2007) 1689-1710.

https://doi.org/10.1016/j.biomaterials.2006.11.042
[4] Wienke H., Sawitowski T., Wnendt S., Fischer A., Dirsch O., Karoussos I. A., Erbel R.: Stent Coating: A new approach in interventional cardiology. Herz, 27/6. (2002) 518-526.

https://doi.org/10.1007/s00059-002-2405-4

[5] De Scheerder I., Sohier J., Wang K., Verbeken E., Zhou X. R., Froyen L., van Humbeeck J., Piessens J., van de Werf F.: Metallic Surface Treatment Using Electrochemical Polishing Decreases Thrombogenicity and Neointimal Hyperlesia of Coronary Stents. Journal of Interventional Cardiology, 13/3. (2007) 179-185.

https://doi.org/10.1111/j.1540-8183.2000. tb00286.x

[6] Lutter C., Nothhaft M., Rzany A., Garlichs C. D., Cicha I.: Effect of specific surface microstructures on substrate endothelialisation and thrombogenicity: Importance for stent design. Clinical Hemorheology and Microcirculation, 59/3. (2015) 219-233.

https://doi.org/10.3233/CH-141839

[7] Horicsányi K., Asztalos L., Károly D., Fazakas É.: Effect of Expansion Pressure ont he Drug Eluting Coating of Coronary Stents. Acta Materialia Transylvanica, 1/1. (2018) 37-40.

https://doi.org/10.2478/amt-2018-0012

[8] Sélley T. L., Terdik A. A., Bognár E.: Biológailag lebomló polimerbevonatok tapadásának vizsgálata. Fiatal Müszakiak Tudományos Ülésszaka, 18. (2013). 359-362. https://doi.org/10.36243/fmtu-2013.78

[9] Sojitra P., Engineer C., Raval A., Kothwala D. M.: Surface enhancement and characterization of L-605 cobalt alloy cardiovascular stent by novel electrochemical treatment. Trends in Biomaterials and Artificial Organs, 23/2. (2009) 55-64.

[10] Diaz-Rodriguez S., Chevallier P., Paternoster C., Montaño-Machado V., Noël C., Houssiaub L., Mantovani D.: Surface modification and direct plasma amination of $\mathrm{L} 605 \mathrm{CoCr}$ alloys: on the optimization of the oxide layer for application in cardiovascular implants. RSC Advances, 9/4. (2019) 2292-2301.

https://doi.org/10.1039/C8RA08541B

[11] Gellér Zs. E., Albrecht K., Dobránszky J.: Electropolishing of coronary stents. Materials Science Forum, 589. (2008) 367-372.

https://doi.org/10.4028/www.scientific.net/ MSF.589.367

[12] Zhao H., Van Humbeeck J., Sohier J., De Scheerder I.: Electrochemical polishing of $316 L$ stainless steel slotted tube coronary stents. Journal of Materials Science: Materials in Medicine, 13. (2002) 911-916.

https://doi.org/10.1023/A:1019831808503

[13] Ozsváth P., Bognár E.: Sztentbevonatok tapadásának vizsgálata és fejlesztése. Anyagok Világa, 1/18. (2010) 1-9. 